\title{
Vaginal Polyp
}

National Cancer Institute

\section{Source}

National Cancer Institute. Vaginal Polyp. NCI Thesaurus. Code C3664.

A benign polypoid lesion arising from the vaginal wall. 